
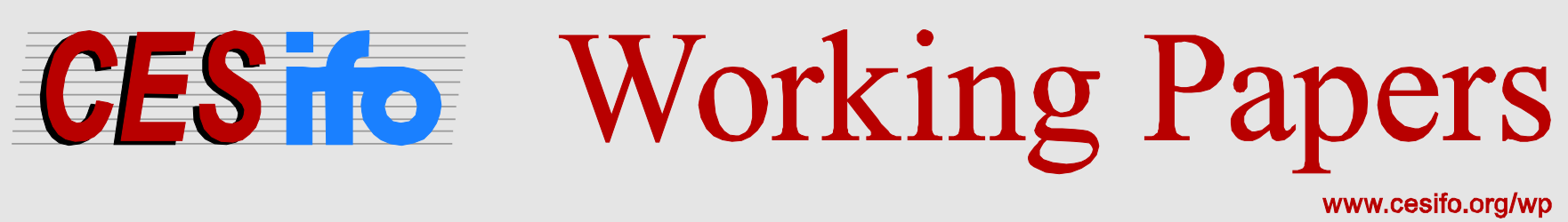

\title{
Outside the State - the Shadow Economy and Shadow Economy Labor Force
}

\author{
Friedrich Schneider
}

CESIFO WORKING PAPER NO. 4829

CAtegory 1: Public FinAnCE

JUNE 2014
An electronic version of the paper may be downloaded
- from the SSRN website: Www.SSRN.com
- from the RePEc website: Www.RePEc.org
- from the CESifo website: www.CESifo-group.org/wp

\section{CESifo}




\title{
Outside the State - the Shadow Economy and Shadow Economy Labor Force
}

\begin{abstract}
In this paper the main focus lies on the shadow economy and on work in the shadow. The most influential factors on the shadow economy are tax policies and state regulation. The size of the shadow economy was decreasing over 1999 to 2007 from $34.0 \%$ to $31.2 \%$ for 161 countries (unweighted average). Furthermore, economic opportunities, taxes and regulations, the general situation on the labor market, and unemployment are crucial for an under-standing of the dynamics of the shadow labor force. Opposite to the decrease of the shadow economy (value added figures), the shadow economy labor force increased for most countries over the period 1999 to 2007.
\end{abstract}

JEL-Code: K420, H260, D780.

Keywords: shadow economy, undeclared work, shadow labor force, tax morale, tax pressure, state regulation, labor market.

\author{
Friedrich Schneider \\ Department of Economics \\ Johannes Kepler University of Linz \\ Altenbergerstr. 69 \\ Austria - 4040 Linz \\ friedrich.schneider@jku.at
}

May 23, 2014 


\section{INTRODUCTION}

Fighting tax evasion, the shadow economy and informal (illegal or shadow) employment have been important policy goals in OECD countries during recent decades. In order to do this one should have knowledge about the size and development of the shadow economy and shadow economy labor force as well as the reasons why people are engaged in shadow economy activities. This is the content of this paper. Tax evasion is not considered in order to keep the subject of this paper tractable and because too many additional aspects would be involved ${ }^{1}$. Also tax morale or experimental studies on tax compliance are beyond the scope of this paper $^{2}$.

My paper is organized as follows: Section 2 presents theoretical considerations about the definition and measurement of the shadow economy and discusses also the main factors determining its size. In Section 3 the empirical results of the size and development of the shadow economy are discussed. In Section 4 a discussion of the size and development of the shadow economy labor force is presented. Finally Section 5 concludes.

\section{SOME THEORETICAL CONSIDERATIONS ABOUT THE SHAD- OW ECONOMY}

\subsection{Defining the Shadow Economy}

Up to today, authors trying to measure the shadow economy face the difficulty of a precise definition of the shadow economy. ${ }^{3}$ According to one commonly used definition it comprises all currently unregistered economic activities that contribute to the officially calculated Gross

1. See Andreoni, Erard and Feinstein (1998) for the authoritative survey, Feld and Frey (2007) or Kirchler (2007) for broader interdisciplinary approaches, or the papers by Kirchler, Maciejovsky and Schneider (2003), Kastlunger, Kirchler, Mittore and Pitters (2009), Kirchler, Hoelzl and Wahl (2007).

2. The authoritative scientific work on tax morale is by Torgler (2007). See also Torgler (2002) for a survey on experimental studies and Blackwell (2010) for a meta-analysis.

3. My paper focuses on the size and development of the shadow economy for uniform countries and not for specific regions. Recently first studies have been undertaken to measure the size of the shadow economy as well as the "grey" or "shadow" labor force for urban regions or states (e.g. California). See e.g. Marcelli, Pastor and Joassart (1999), Marcelli (2004), Chen (2004), Williams and Windebank (1998, 2001a, b), Flaming, Hayolamak, and Jossart (2005), Alderslade, Talmage and Freeman (2006), Brück, HaistenDeNew and Zimmermann (2006). Herwartz, Schneider and Tafenau (2009) and Tafenau, Herwartz and Schneider (2010) estimate the size of the shadow economy of 234 EU-NUTS regions for the year 2004 for the first time demonstrating a considerable regional variation in the size of the shadow economy. 
National Product. ${ }^{4}$ Smith (1994, p. 18) defines it as "market-based production of goods and services, whether legal or illegal, that escapes detection in the official estimates of GDP". Put differently, one of the broadest definitions is: “...those economic activities and the income derived from them that circumvent or otherwise avoid government regulation, taxation or observation". 5

In this paper the following more narrow definition of the shadow economy is used. ${ }^{6}$ The shadow economy includes all market-based legal production of goods and services that are deliberately concealed from public authorities for the following reasons:

1. to avoid payment of income, value added or other taxes,

2. to avoid payment of social security contributions,

3. to avoid having to meet certain legal labor market standards, such as minimum wages, maximum working hours, safety standards, etc., and

4. to avoid complying with certain administrative obligations, such as completing statistical questionnaires or other administrative forms.

Thus, I will not deal with typically illegal underground economic activities that fit the characteristics of classical crimes like burglary, robbery, drug dealing, etc. I also exclude the informal household economy which consists of all household services and production.

\subsection{Measuring the Shadow Economy ${ }^{7}$}

The definition of the shadow economy plays an important role in assessing its size. By having a clear definition, a number of ambiguities and controversies can be avoided. In general, there are two types of shadow economic activities: illicit employment and the in the household produced goods and services mostly consumed within the household. ${ }^{8}$ The following analysis focuses on both types, but tries to exclude illegal activities such as drug production, crime and human trafficking. The in the household produced goods and services, e.g. schooling and

4. This definition is used, e.g., by Feige (1989, 1994), Schneider (1994a, 2003, 2005) and Frey and Pommerehne (1984). Do-it-yourself activities are not included. For estimates of the shadow economy and the doit-yourself activities for Germany see Buehn, Karmann und Schneider (2009) or Karmann (1986, 1990).

5. This definition is taken from Dell'Anno (2003), Dell'Anno and Schneider (2004) and Feige (1989); see also Thomas (1999), Fleming, Roman and Farrell (2000) or Feld and Larsen (2005, p. 25).

6. See also the excellent discussion of the definition of the shadow economy in Pedersen (2003, pp.13-19) and Kazemier (2005a) who use a similar one.

7. Compare also Feld and Schneider (2010), Schneider (2011) and Schneider and Williams (2013).

8. For a broader discussion of the definition issue see Thomas (1992), Schneider, Volkert and Caspar (2002), Schneider and Enste (2002, 2006), Kazemier (2005a, b) and Buehn, Karmann and Schneider (2009). 
childcare are not part of this analysis. Thus, it only focuses on productive economic activities that would normally be included in the national accounts but which remain underground due to tax or regulatory burdens. ${ }^{9}$ Although such legal activities contribute to the country's value added, they are not captured in the national accounts because they are produced in illicit ways (e.g. by people without proper qualification or without a master craftsman's certificate). From the economic and social perspective, soft forms of illicit employment, such as moonlighting (e.g. construction work in private homes) and its contribution to aggregate value added can be assessed rather positively.

Although the issue of the shadow economy has been investigated for a long time, the discussion regarding the "appropriate" methodology to assess its scope has not come to an end yet. ${ }^{10}$ There are three methods of assessment:

(1) Direct procedures at a micro level that aim at determining the size of the shadow economy at one particular point in time. An example is the survey method;

(2) Indirect procedures that make use of macroeconomic indicators in order to proxy the development of the shadow economy over time;

(3) Statistical models that use statistical tools to estimate the shadow economy as an "unobserved" variable.

Today in many cases the estimation of the shadow economy is based on a combination of the MIMIC procedure and on the currency demand method; or the use of only the currency demand method. ${ }^{11}$ The MIMIC procedure assumes that the shadow economy remains an unobserved phenomenon (latent variable) which can be estimated using quantitatively measurable causes of illicit employment, e.g. tax burden and regulation intensity, and indicators reflecting illicit activities, e.g. currency demand, official GDP and official working time. A disadvantage of the MIMIC procedure is the fact, that it produces only relative estimates of the size

9. With this definition the problem of having classical crime activities included could be avoided, because neither the MIMIC procedure nor the currency demand approach captures these activities: e.g. drug dealing is independent of increasing taxes, especially as the included causal variables are not linked (or causal) to classical crime activities. See e.g. Thomas (1992), Kazemir (2005a, b) and Schneider (2005).

10. For the strengths and weaknesses of the various methods see Bhattacharyya (1999), Breusch (2005a, b), Dell'Anno and Schneider (2009), Dixon (1999), Feige (1989), Feld and Larsen (2005), Feld and Schneider (2010), Giles (1999a, b, c), Schneider (1986, 2001, 2003, 2005, 2006, 2011), Schneider and Enste (2000a, b, 2002, 2006), Tanzi (1999), Thomas (1992, 1999).

11. These methods are presented in detail in Schneider (1994a, b, c, 2005, 2011), Schneider and Williams (2013), Feld and Schneider (2010) and Schneider and Enste (2000b, 2002, 2006). Furthermore, these studies discuss advantages and disadvantages of the MIMIC- and the money demand methods as well as other estimation methods for assessing the size of illicit employment; for a detailed discussion see also Feld and Larsen (2005). 
and the development of the shadow economy. Thus, the currency demand method ${ }^{12}$ is used to calibrate the relative into absolute estimates (e.g. in percent of GDP) by using two or three absolute values (in percent of GDP) of the size of the shadow economy.

In addition, the size of the shadow economy is estimated by using survey methods (Feld and Larsen $(2005,2008,2009))$. In order to minimize the number of respondents dishonestly replying or totally declining answers to the sensitive questions, structured interviews are undertaken (usually face-to-face) in which the respondents are slowly getting accustomed to the main purpose of the survey. Like it is done by the contingent valuation method (CVM) in environmental economics (Kopp et al. 1997), a first part of the questionnaire aims at shaping respondents' perception as to the issue at hand. In a second part, questions about respondents' activities in the shadow economy are asked, and the third part contains the usual sociodemographic questions.

In addition to the studies by Merz and Wolff (1993), Feld and Larsen (2005, 2008, 2009), Haigner et al. (2011) and Enste and Schneider (2006) for Germany, the survey method has been applied in the Nordic countries and Great Britain (Isachsen and Strøm 1985, Pedersen 2003) as well as in the Netherlands (van Eck and Kazemier 1988, Kazemier 2006). While the questionnaires underlying these studies are broadly comparable in design, recent attempts by the European Union to provide survey results for all EU member states runs into difficulties regarding comparability (Renooy et al. 2004, European Commission 2007): the wording of the questionnaires becomes more and more cumbersome depending on the culture of different countries with respect to the underground economy.

To summarize: Although each method has its strength and weaknesses, and biases in the estimates of the shadow economy almost certainly prevail, no better data are currently available. Clearly, there can be no exact measure of the size of the shadow economy and estimates differ widely with an error margin of $+/-15$ percent. These days, macro estimates derived from the MIMIC model, the currency demand method, or the electricity approach are seen as upper bound estimates, while micro (survey) estimates are seen as lower bound estimates.

12. This indirect approach is based on the assumption that cash is used to make transactions within the shadow economy. By using this method one econometrically estimates a currency demand function including independent variables like tax burden, regulation etc. which "drive" the shadow economy. This equation is used to make simulations of the amount of money that would be necessary to generate the official GDP. This amount is then compared with the actual money demand and the difference is treated as an indicator for the development of the shadow economy. On this basis the calculated difference is multiplied by the velocity of money of the official economy and one gets a value added figure for the shadow economy. See footnote 11 for references discussing critically this method. 


\subsection{The Main Causes Determining the Shadow Economy}

Table 2.1 presents an overview of the most important determinants influencing the shadow economy. Due to space reasons, there is no detailed discussion of the various determinants/causes of the shadow economy. 
Table 2.1: The main causes determining the shadow economy

\begin{tabular}{|c|c|c|}
\hline Causal variable & Theoretical reasoning & References \\
\hline $\begin{array}{l}\text { Tax and Social Securi- } \\
\text { ty Contribution Bur- } \\
\text { dens }\end{array}$ & $\begin{array}{l}\text { The distortion of the overall tax burden affects labor-leisure choices and may stimu- } \\
\text { late labor supply in the shadow economy. The bigger the difference between the total } \\
\text { labor cost in the official economy and after-tax earnings (from work), the greater is } \\
\text { the incentive to reduce the tax wedge and to work in the shadow economy. This tax } \\
\text { wedge depends on social security burden/payments and the overall tax burden, mak- } \\
\text { ing them to key determinants for the existence of the shadow economy. }\end{array}$ & $\begin{array}{l}\text { E.g. Thomas (1992), Johnson, } \\
\text { Kaufmann, and Zoido-Lobatón } \\
\text { (1998a,b), Giles (1999a), Tanzi } \\
\text { (1999), Schneider (2003, 2005), } \\
\text { Dell'Anno (2007), Dell'Anno, } \\
\text { Gomez-Antonio and Alanon Pardo } \\
\text { (2007), Buehn and Schneider } \\
\text { (2012) }\end{array}$ \\
\hline Quality of Institutions & $\begin{array}{l}\text { The quality of public institutions is another key factor for the development of the } \\
\text { informal sector. Especially the efficient and discretionary application of the tax code } \\
\text { and regulations by the government plays a crucial role in the decision to work under- } \\
\text { ground, even more important than the actual burden of taxes and regulations. In par- } \\
\text { ticular, a bureaucracy with highly corrupt government officials seems to be associated } \\
\text { with larger unofficial activity, while a good rule of law by securing property rights } \\
\text { and contract enforceability increases the benefits of being formal. A certain level of } \\
\text { taxation, mostly spent in productive public services, characterizes efficient policies. } \\
\text { In fact, the production in the formal sector benefits from a higher provision of pro- } \\
\text { ductive public services and is negatively affected by taxation, while the shadow } \\
\text { economy reacts in the opposite way. An informal sector developing as a consequence } \\
\text { of the failure of political institutions in promoting an efficient market economy, and } \\
\text { entrepreneurs going underground, as there is an inefficient public goods provision, } \\
\text { may reduce if institutions can be strengthened and fiscal policy gets closer to the me- } \\
\text { dian voter's preferences. }\end{array}$ & $\begin{array}{l}\text { E.g. Johnson et al. (1998a,b), } \\
\text { Friedman, Johnson, Kaufmann, } \\
\text { and Zoido-Lobaton (2000), Dreher } \\
\text { and Schneider (2009), Dreher, } \\
\text { Kotsogiannis and Macorriston } \\
\text { (2009), Schneider (2010), Buehn } \\
\text { and Schneider (2012), Teobaldelli } \\
\text { (2011), Teobaldelli and Schneider } \\
\text { (2012), Amendola and Dell'Anno } \\
\text { (2010), Losby et al. (2002), } \\
\text { Schneider and Williams (2013) }\end{array}$ \\
\hline Regulations & $\begin{array}{l}\text { Regulations, for example labor market regulations or trade barriers, are another im- } \\
\text { portant factor that reduces the freedom (of choice) for individuals in the official } \\
\text { economy. They lead to a substantial increase in labor costs in the official economy } \\
\text { and thus provide another incentive to work in the shadow economy: countries that are } \\
\text { more heavily regulated tend to have a higher share of the shadow economy in total } \\
\text { GDP. Especially the enforcement and not the overall extent of regulation - mostly not } \\
\text { enforced - is the key factor for the burden levied on firms and individuals, making } \\
\text { them operate in the shadow economy. }\end{array}$ & $\begin{array}{l}\text { E.g. Johnson, Kaufmann, and } \\
\text { Shleifer (1997), Johnson, Kauf- } \\
\text { mann, and Zoido-Lobatón } \\
\text { (1998b), Friedman, Johnson, } \\
\text { Kaufmann, and Zoido-Lobaton } \\
\text { (2000), Kucera and Roncolato } \\
\text { (2008), Schneider (2011) }\end{array}$ \\
\hline
\end{tabular}


Table 2.1: The main causes determining the shadow economy (cont.)

\begin{tabular}{|c|c|c|}
\hline Causal variable & Theoretical reasoning & References \\
\hline Public Sector Services & $\begin{array}{l}\text { An increase of the shadow economy may lead to fewer state revenues, which in turn } \\
\text { reduce the quality and quantity of publicly provided goods and services. Ultimately, } \\
\text { this may lead to increasing tax rates for firms and individuals, although the deteriora- } \\
\text { tion in the quality of the public goods (such as the public infrastructure) and of the } \\
\text { administration continues. The consequence is an even stronger incentive to partici- } \\
\text { pate in the shadow economy. Countries with higher tax revenues achieved by lower } \\
\text { tax rates, fewer laws and regulations, a better rule of law and lower corruption levels, } \\
\text { should thus have smaller shadow economies. }\end{array}$ & $\begin{array}{l}\text { E.g. Johnson, Kaufmann, and } \\
\text { Zoido-Lobatón (1998a,b), Feld } \\
\text { and Schneider (2010) }\end{array}$ \\
\hline Tax Morale & $\begin{array}{l}\text { The efficiency of the public sector also has an indirect effect on the size of the shad- } \\
\text { ow economy because it affects tax morale. Tax compliance is driven by a psychologi- } \\
\text { cal tax contract that entails rights and obligations from taxpayers and citizens on the } \\
\text { one hand, but also from the state and its tax authorities on the other hand. Taxpayers } \\
\text { are more heavily inclined to pay their taxes honestly if they get valuable public ser- } \\
\text { vices in exchange. However, taxpayers are honest even in cases when the benefit } \\
\text { principle of taxation does not hold, i.e. for redistributive policies, if such political } \\
\text { decisions follow fair procedures. The treatment of taxpayers by the tax authority also } \\
\text { plays a role. If taxpayers are treated like partners in a (tax) contract instead of subor- } \\
\text { dinates in a hierarchical relationship, taxpayers will stick to their obligations of the } \\
\text { psychological tax contract more easily. Hence, (better) tax morale and (stronger) so- } \\
\text { cial norms may reduce the probability of individuals to work underground. }\end{array}$ & $\begin{array}{l}\text { E.g. Feld and Frey (2007), Kirch- } \\
\text { ler (2007), Torgler and Schneider } \\
\text { (2009), Feld and Larsen (2005, } \\
\text { 2009), Feld and Schneider (2010) }\end{array}$ \\
\hline Deterrence & $\begin{array}{l}\text { Despite the strong focus on deterrence in policies fighting the shadow economy and } \\
\text { the unambiguous insights of the traditional economic theory of tax non-compliance, } \\
\text { surprisingly little is known about the effects of deterrence from empirical studies. } \\
\text { This is due to the fact that data on the legal background and the frequency of audits } \\
\text { are not available on an international basis; even for OECD countries such data is dif- } \\
\text { ficult to collect. Either is the legal background quite complicated differentiating fines } \\
\text { and punishment according to the severity of the offense and the true income of the } \\
\text { non-complier, or tax authorities do not reveal how intensively auditing is taking } \\
\text { place. The little empirical survey evidence available demonstrates that fines and pun- } \\
\text { ishment do not exert a negative influence on the shadow economy, while the subjec- } \\
\text { tively perceived risk of detection does. However, the results are often weak and } \\
\text { Granger causality tests show that the size of the shadow economy can impact deter- } \\
\text { rence instead of deterrence reducing the shadow economy. }\end{array}$ & $\begin{array}{l}\text { E.g. Andreoni, Erard and Feinstein } \\
\text { (1998), Pedersen (2003), Feld and } \\
\text { Larsen }(2005,2009), \text { Feld and } \\
\text { Schneider }(2010)\end{array}$ \\
\hline
\end{tabular}


Table 2.1: The main causes determining the shadow economy (cont.)

\begin{tabular}{|c|c|c|}
\hline Causal variable & Theoretical reasoning & References \\
\hline Agricultural Sector & $\begin{array}{l}\text { The importance of agriculture in the economy is included, since many studies endorse } \\
\text { the idea that informal work is concentrated in highly segmented sectors, with clear } \\
\text { prevalence for the agricultural and related sectors. One of the most important reasons } \\
\text { for this is the minimum enforcement capacity of governments prevalent in rural areas. } \\
\text { The importance of agriculture is measured as the share of agriculture as percentage of } \\
\text { GDP. The larger the agricultural sector, the larger the expected size of the shadow } \\
\text { economy, ceteris paribus. }\end{array}$ & $\begin{array}{l}\text { E.g. Vuletin (2008), De la Roca, } \\
\text { Hernandez, Robles, Torero and } \\
\text { Webber (2002), Greenidge, Hold- } \\
\text { er and Mayers (2005), Mootoo, } \\
\text { Sookram and Watson (2002), } \\
\text { Amendola and Dell'Anno (2010), } \\
\text { Losby et al. (2002) }\end{array}$ \\
\hline $\begin{array}{l}\text { Development of the } \\
\text { official economy }\end{array}$ & $\begin{array}{l}\text { The development of the official economy is another key factor of the shadow econo- } \\
\text { my. The higher (lower) the unemployment quota (GDP-growth), the higher is the } \\
\text { incentive to work in the shadow economy, ceteris paribus. }\end{array}$ & $\begin{array}{l}\text { Schneider and Williams (2013) } \\
\text { Feld and Schneider (2010) }\end{array}$ \\
\hline Self-employment & $\begin{array}{l}\text { The higher self-employment is, the more activities can be done in the shadow econo- } \\
\text { my, ceteris paribus. }\end{array}$ & $\begin{array}{l}\text { Schneider and Williams (2013) } \\
\text { Feld and Schneider (2010) }\end{array}$ \\
\hline
\end{tabular}




\section{SIZE OF THE SHADOW ECONOMIES ALL OVER THE WORLD ${ }^{13}$}

Figure 3.1 shows the average size of the shadow economy of 162 countries over 1999-2007. In tables 3.1 und 3.2 the average informality (unweighted and weighted) in different regions is shown using the regions defined by the World Bank. The World Bank distinguishes 8 world regions which are East Asia and Pacific, Europe and Central Asia, Latin America and the Caribbean, Middle East and North Africa, High Income OECD, Other High Income, South Asia, and Sub-Saharan Africa. If we consider first table 3.1 where the average informality (unweighted) is shown, we see that Latin America and the Caribbean have the highest value of the shadow economies of $41.1 \%$, followed by Sub-Saharan Africa of $40.2 \%$ and then followed by Europe and Central Asia of 38.9\%. The lowest have the High Income OECD countries with $17.1 \%$. If we consider the average informality of the shadow economies of these regions weighted by total GDP in 2005, Sub-Saharan Africa has the highest with $37.6 \%$, followed by Europe and Central Asia with 36.4\% and Latin America and the Caribbean with $34.7 \%$. The lowest again has the High Income OECD with $13.4 \%$. If one considers the world mean weighted and unweighted, one sees that if one uses the unweighted measures the mean is $33.0 \%$ over the periods 1999-2007. If we consider the world with weighted informality measures the shadow economy takes "only" a value of $17.1 \%$ over the period 1999-2007. Weighting the values makes a considerable difference.

One general result of the size and development of the shadow economies worldwide is that there is an overall reduction in the size. In figure 3.2 the size and development of the shadow economy of various countries groups (weighted averages by the official GDP of 2005) over 1999, 2003 and 2007 are shown. One clearly realizes that for all countries groups (25 OECD countries, 116 developing counties, 25 transition countries) I observe a decrease in the size of the shadow economy. The average size of the shadow economies of the 162 countries was $34.0 \%$ of official GDP (unweighted measure!) in 1999 and decreased to $31.2 \%$ of official GDP in 2007. This is a decrease of almost 3.0 percentage points over 9 years. Growth of the official economy with reduced (increased) unemployment (employment) seems to be the most efficient mean to reduce the shadow economy.

13. Some figures are taken from Schneider, Buehn and Montenegro (2010). The econometric MIMIC estimation results are not shown here due to space reasons; see e.g. Schneider, Buehn and Montenegro (2010). 
Table 3.1: Average Informality (Unweighted) by World Bank's Regions

\begin{tabular}{|c|c|c|c|c|c|c|}
\hline & Region & mean & median & $\min$ & $\max$ & sd \\
\hline EAP & East Asia and Pacific & 32.3 & 32.4 & 12.7 & 50.6 & 13.3 \\
\hline ECA & Europe and Central Asia & 38.9 & 39.0 & 18.1 & 65.8 & 10.9 \\
\hline LAC & Latin America and the Caribbean & 41.1 & 38.8 & 19.3 & 66.1 & 12.3 \\
\hline MENA & Middle East and North Africa & 28.0 & 32.5 & 18.3 & 37.2 & 7.8 \\
\hline OECD & High Income OECD & 17.1 & 15.8 & 8.5 & 28.0 & 6.1 \\
\hline OHIE & Other High Income & 23.0 & 25.0 & 12.4 & 33.4 & 7.0 \\
\hline SAS & South Asia & 33.2 & 35.3 & 22.2 & 43.9 & 7.0 \\
\hline SSA & Sub-Saharan Africa & 40.2 & 40.6 & 18.4 & 61.8 & 8.3 \\
\hline World & & 33.0 & 33.5 & 8.5 & 66.1 & 12.8 \\
\hline
\end{tabular}

Source: Schneider, Buehn and Montenegro (2010) 
Table 3.2: Average Informality (Weighted) by Total GDP in 2005

\begin{tabular}{|c|c|c|c|c|c|c|}
\hline & Region & Mean & median & $\min$ & $\max$ & sd \\
\hline EAP & East Asia and Pacific & 17.5 & 12.7 & 12.7 & 50.6 & 10.6 \\
\hline ECA & Europe and Central Asia & 36.4 & 32.6 & 18.1 & 65.8 & 8.4 \\
\hline LAC & Latin America and the Caribbean & 34.7 & 33.8 & 19.3 & 66.1 & 7.9 \\
\hline MENA & Middle East and North Africa & 27.3 & 32.5 & 18.3 & 37.2 & 7.7 \\
\hline OECD & High Income OECD & 13.4 & 11.0 & 8.5 & 28.0 & 5.7 \\
\hline OHIE & Other High Income & 20.8 & 19.4 & 12.4 & 33.4 & 4.9 \\
\hline SAS & South Asia & 25.1 & 22.2 & 22.2 & 43.9 & 5.9 \\
\hline SSA & Sub-Saharan Africa & 37.6 & 33.2 & 18.4 & 61.8 & 11.7 \\
\hline World & & 17.1 & 13.2 & 8.5 & 66.1 & 9.9 \\
\hline
\end{tabular}

Source: Schneider, Buehn and Montenegro (2010) 
Figure 3.1: Average Size of the Shadow Economy of 162 Countries over 1999-2007

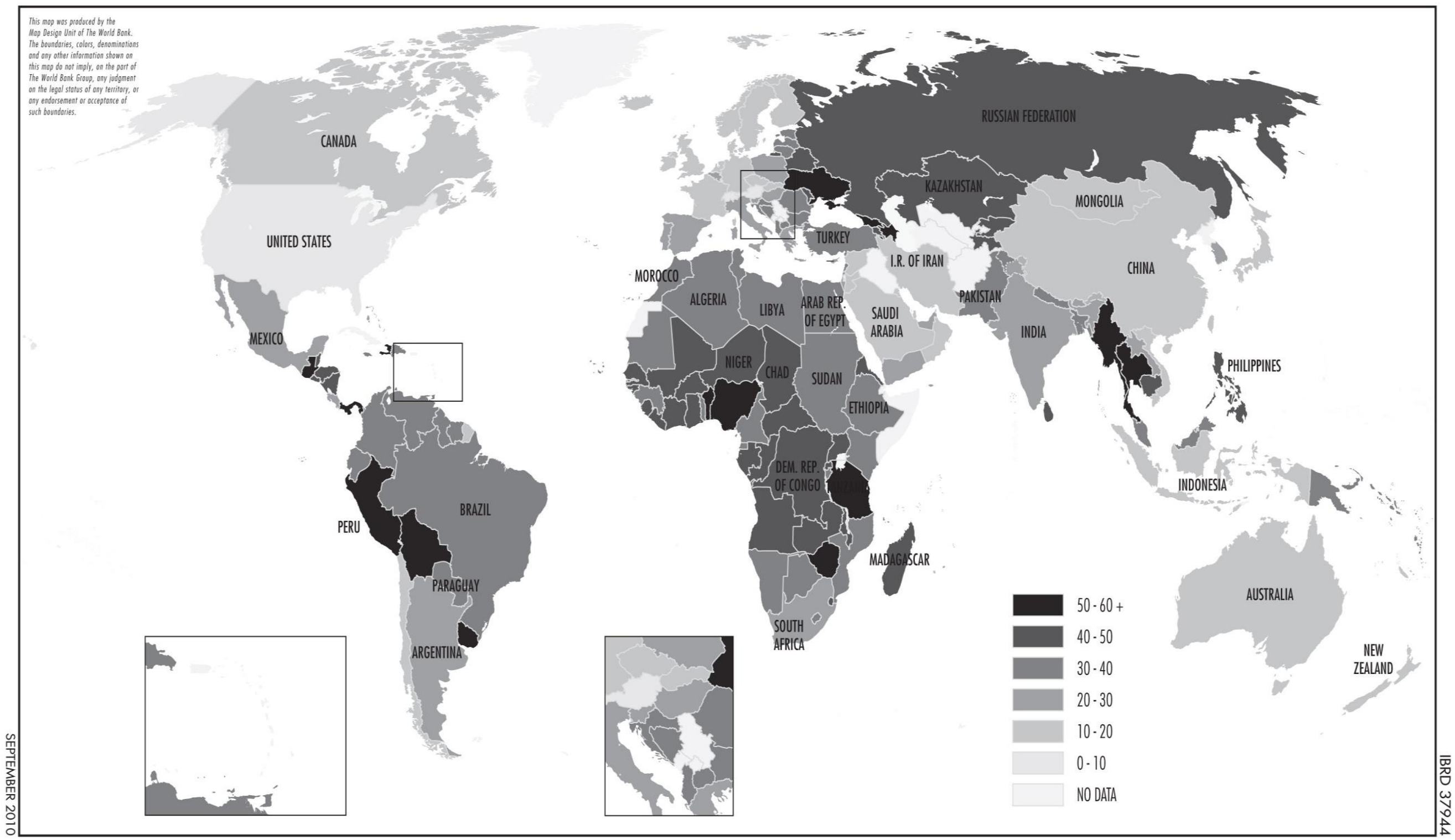

Source: Schneider, Buehn and Montenegro (2010) 
Figure 3.2: Size and Development of the Shadow Economy of Various Countries Groups (Weighted Averages (!); in percent of official total GDP of the respective Country Group)

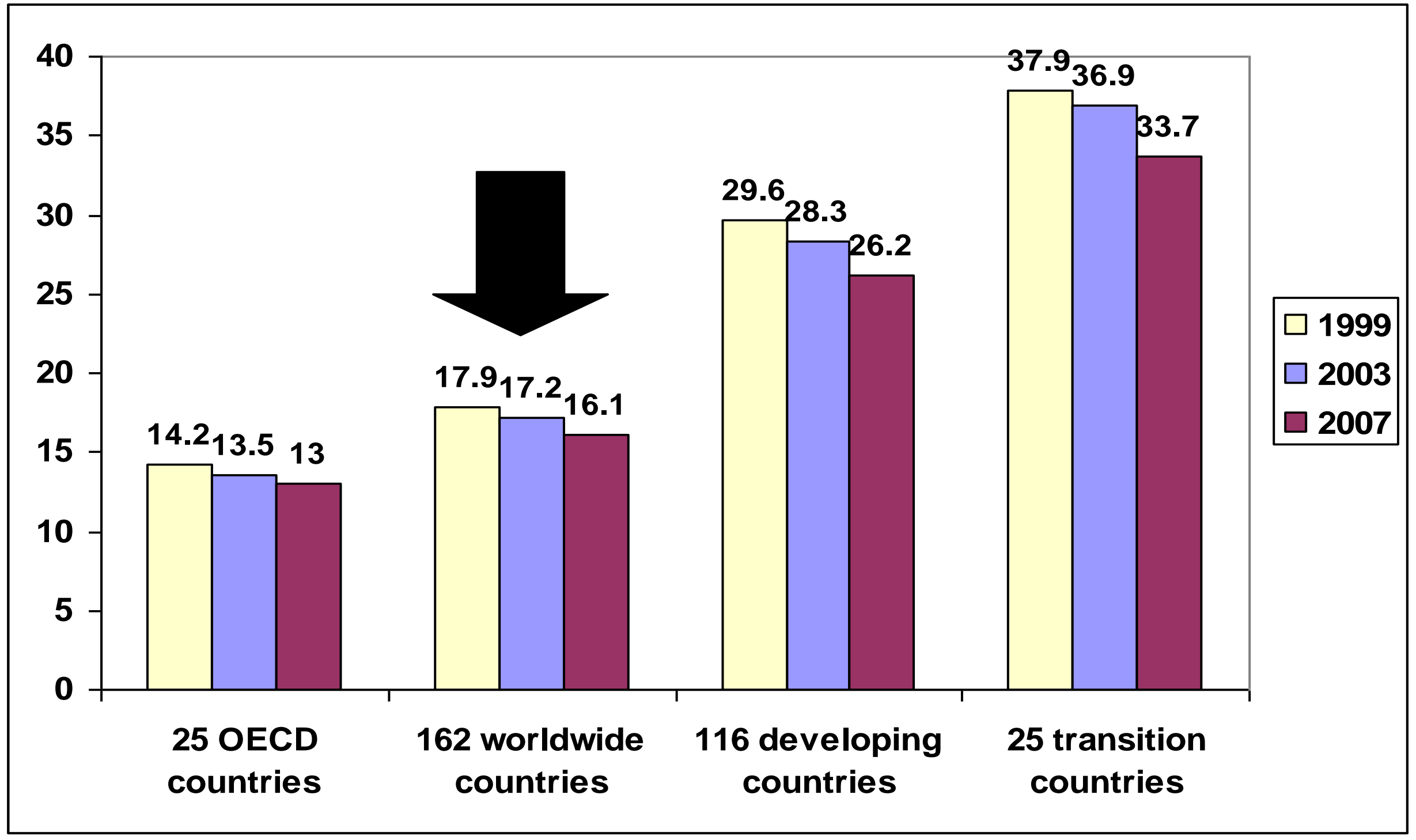

Source: Schneider, Buehn and Montenegro (2010) 


\section{SHADOW ECONOMY LABOR FORCE}

The following results of the shadow economy labor force are based on the OECD and World Bank database on informal employment in major cities and in rural areas, as well as on other sources mentioned in the footnotes of this chapter and the tables. The values of the shadow economy labor force are calculated in absolute terms, and as a percentage of the official labor force, under the assumption that the shadow economy in rural areas is at least as high as in the cities. This is a conservative assumption, since in reality it is likely to be even larger. ${ }^{14}$ Survey techniques and, for some countries, the MIMIC-method and the method of the discrepancy between the official and actual labor force are used for estimation.

One of the most famous studies is the OECD (2009a, b) one with the title "Is informal normal?", which provides worldwide figures. This OECD study ${ }^{15}$ concludes that in many parts of the world and over the period 1990 to 2007 informal employment is the norm, not the exception,. More than half of all jobs in the non-agricultural sectors of developing countries - over 900 million workers - can be considered informal. If agricultural workers in developing countries are included, the estimates size to roughly 2,000 million people. The share of informal employment is also shown in figure 4.1 for Latin America and South East Asia. In some regions, including Sub-Saharan Africa and South Asia, over $80 \%$ of non-agricultural jobs are informal. Most informal workers in the developing world are self-employed and work independently, or owe and manage very small enterprises. According to the OECD study (2009a, b), informal employment is a result of both, people being excluded from official jobs and people voluntarily opting out of formal structures, e.g. in many middle income countries incentives drive individuals and businesses out of the formal sector.

To summarize, this OECD study clearly comes to the conclusion that informal is really the norm or the normal case. 1.8 billion people work in informal jobs, compared to 1.2 billion who benefit from formal contracts and social security protection. Informal economic activity, excluding the agricultural sector, accounts for three quarters of the jobs in Sub-Saharan Africa, for more than two thirds in South and South East Asia, half in Latin America, the Middle East and North Africa, and nearly for one quarter in transition countries. If agriculture is included, the informal share of the economy in the above mentioned regions is even higher (e.g.

14. The assumption that the shadow economy labour force is at least as high in rural areas as in major cities, is a very modest one and is supported by Lubell (1991). Some authors (e.g., Lubell (1991), Pozo (1996), and Chickering and Salahdine (1991)) argue that the illicit labour force is nearly twice as high in the countryside as in urban areas. But since no (precise) data exists on this ratio, the assumption of an equal size may be justified arguing that such a calculation provides at least minimal figures.

15. The following results and figures are taken from the $\operatorname{OECD}(2009 \mathrm{a}, \mathrm{b})$, executive summary. 
more than $90 \%$ in South Asia). Also, this OECD study comes to the result that more than 700 million informal workers "survive" on less than $\$ 1.25$ a day and some 1.2 billion on less than $\$ 2$ a day. The study also concludes that the share of informal employment tends to increase during economic turmoil. For example, during the Argentine economic crisis (1999-2002), the countries' "official" economy shrank as by almost one fifth while the share of informal employment expanded from 48 to 52 percent. One can clearly see that even under strong economic growth, the share of non-agricultural employment and, the share of informal employment is strongly rising.

Figure 4.1: Informal Employment and GDP in Latin America and Southeast Asia

\section{Part 1: Latin America}

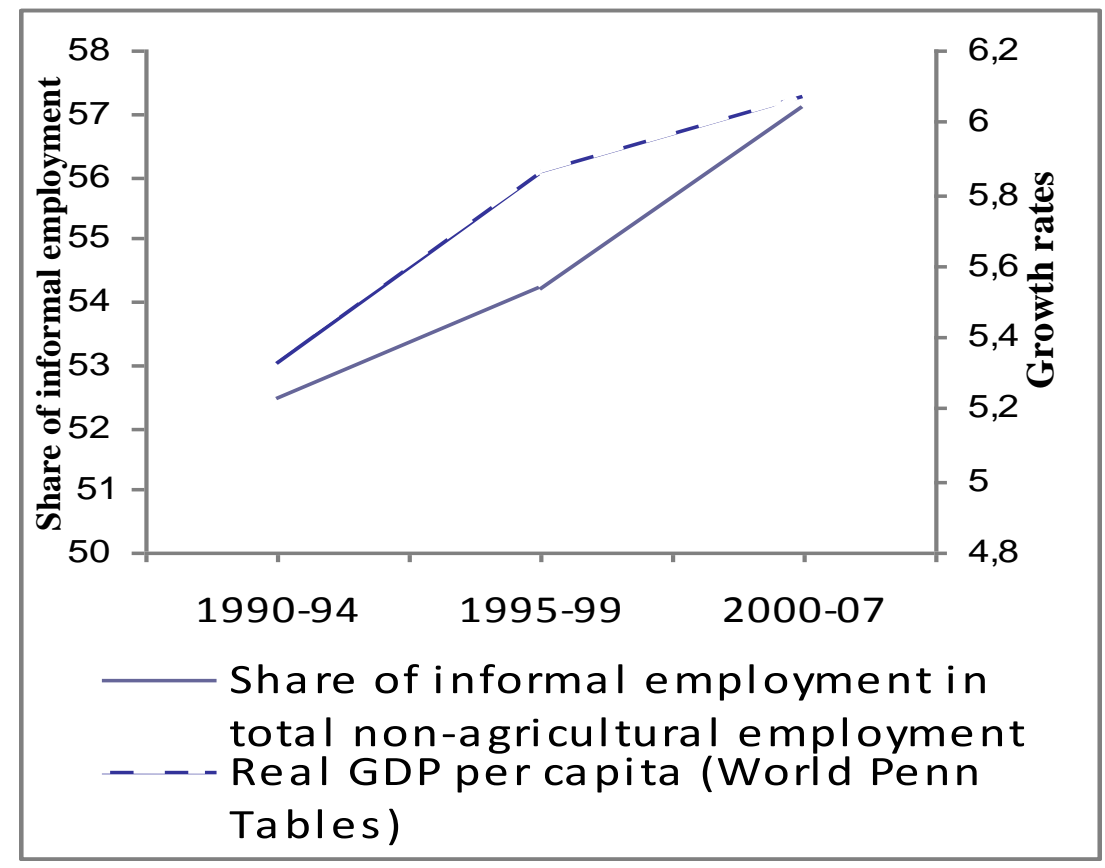




\section{Part 2: $\quad$ Southeast Asia}

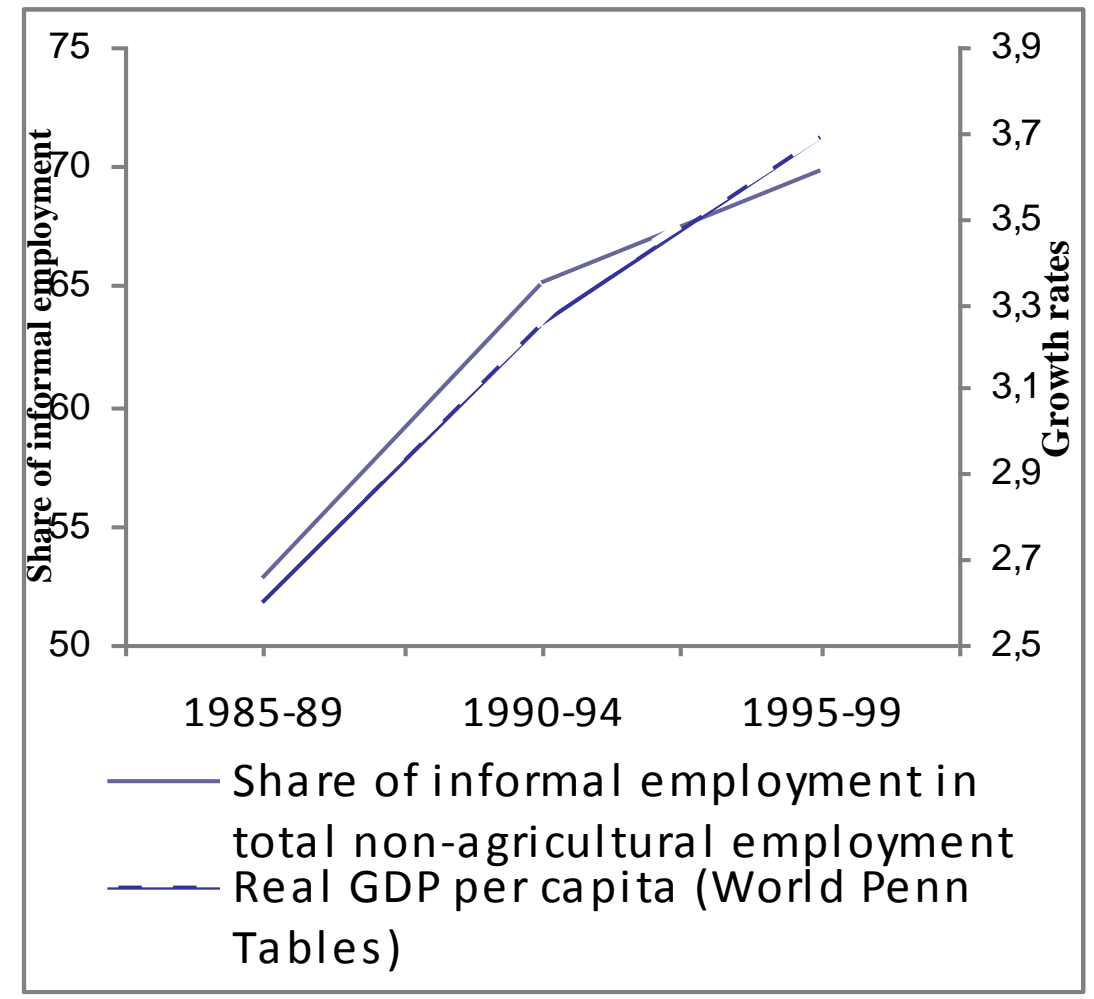

Source: OECD, Is Informal Normal, Paris, 2009a, b.

In table 4.1 the share of informal employment in total non-agricultural employment by fiveyear period and by region is presented. From the table one clearly sees that in all regions the share of informal employment has remarkably increased over time. The share of informal employment in South- and Middle-American countries in the period of 1985-1989 was 32.4\% and increased in the period of 2000-2007 to 50.1\%. In 34 Asian countries informal employment rose in the period of $1985-1989$ from $55.9 \%$ to $70.2 \%$ from $2000-2007$. In the 42 African countries the share of informal employment (in percent of total non agricultural employment) was $40.3 \%$ from $1985-1989$, and increased to $60.5 \%$ in $2000-2007$. Table 4.1 clearly demonstrates that there is a very strong positive trend in the share of informal employment (in percent of total non-agricultural employment). 
Table 4.1: Share of Informal Employment in Total Non-Agricultural Employment by five-year period in \%

\begin{tabular}{|l|c|c|c|c|}
\hline \multirow{2}{*}{ Region } & \multicolumn{3}{|c|}{ Average Share of Informal Employment in \% of Local Non Agricul- } \\
tural Employment over
\end{tabular}

Source: OECD 2009a, b, pages 34-35; and Charmes (2002, 2007, 2008) for the ILO Women and Men in the Informal Economy, 2002.

For the most recent period: Heintz and Chang (2007) for the ILO, and for West Asia: Charmes (2007 and 2008). 


\section{CONCLUSIONS}

In this paper some of the most recent developments in research on the shadow economy and undeclared work in highly developed OECD, developing and transition countries are shown. The discussion of the recent literature shows that economic opportunities for employees, the overall situation on the labor market, not least unemployment are crucial for an understanding of the dynamics of the shadow economy. Individuals look for ways to improve their economic situation and thus contribute productively to aggregate income of a country. This holds regardless of their being active in the official or the unofficial economy.

A last question remaining is: What type of policy conclusions can I draw? One conclusion may be that - besides the indirect tax and personal income tax burden, which the government can directly influence by policy actions - self-employment and unemployment are two very important driving forces of the shadow economy. Unemployment may be controllable by the government through economic policy in a traditional Keynesian sense; alternatively, the government can try to improve the country's competitiveness to increase foreign demand. The impact of self-employment on the shadow economy is less or only partly controllable by the government and may be ambiguous from a welfare perspective. A government can deregulate the economy or incentivize "to be your own entrepreneur", which would make selfemployment easier, potentially reducing unemployment and positively contributing to efforts in controlling the size of the shadow economy. Such actions however need to be accompanied with a strengthening of institutions and tax morale to reduce the probability that selfemployed shift reasonable proportions of their economic activities into the shadow economy, which, if it happened, made government policies incentivizing self-employment less effective. This paper clearly shows that a reduction of the shadow economy can be achieved using various channels the government can influence. The main challenge still is to bring shadow economic activities into the official economy in a way that goods and services previously produced in the shadow economy are still produced and provided but in the official economy. Only then, the government gets additional taxes and social security contributions.

Finally, if I ask what we know about the shadow economy and work in the shadow, I clearly realize that we have some knowledge about the size and development of the shadow economy and the size and development of the shadow economy labor force. For developing countries, the shadow economy labor force has reached a remarkable size according to OECD (2009 a, b) estimates, which is, that in most developing countries the shadow economy labor force is 
higher than the official labor force. What we do not know are the exact motives, why people work in the shadow economy and what is their relation and feeling if a government undertakes reforms in order to bring them back into the official economy. Hence, much more micro studies are needed to obtain a more detailed knowledge about people's motivation to work either the shadow economy and/or in the official one. 


\section{REFERENCES}

Alderslade, J., J. Talmage and Y. Freeman (2006), Measuring the Informal Economy: One Neighborhood at a Time, Discussion Paper, The Brooking Institution Metropolitan Policy Program, Washington D.C., September 2006.

Amendola, A. and R. Dell'Anno (2010), Institutions and Human Development in the Latin America Shadow Economy, Estudios en Derecho y Gobierno 3/1, pp. 9-25.

Andreoni, J., B. Erard and J. Feinstein (1998), Tax Compliance, Journal of Economic Literature 36/4, pp. 818-860.

Bhattacharyya, D.K. (1999), On the Economic Rationale of Estimating the Hidden Economy, Economic Journal 109/3, 348-359.

Blackwell, C. (2010), A Meta Analysis of Incentive Effects in Tax Compliance Experiments, in: J. Alm, J. Martinez-Vazquez and Benno Torgler (eds.), Developing Alternative Frameworks Explaining Tax Compliance, London: Routledge Publishing Company, pp. 97-112.

Breusch, T. (2005a), The Canadian Underground Economy: An Examination of Giles and Tedds, Canadian Tax Journal 53/4, 367-391.

Breusch, T. (2005b), Estimating the Underground Economy Using MIMIC Models, Working Paper, Canberra, Australia, http://econwpa.wustl.edu/eps/em/papers/0507/0507003.pdf.

Brueck, T., J.B. Haisten-DeNew and K.F. Zimmermann (2006), Creating Low-Skilled Jobs by Subsidizing Market Contracted Household Work, Applied Economics 38/4, 899-911.

Buehn, A. and F. Schneider (2012), Shadow Economies Around the World: Novel Insights, Accepted Knowledge, and New Estimates, International Tax and Public Finance 19, 139-171.

Buehn, A., A. Karmann and F. Schneider (2009), Shadow Economy and Do-it-yourself Activities: The German Case, Journal of Institutional and Theoretical Economics, 165/4, pp.701-722.

Charmes, J. (2002), Informal Sector, Poverty and Gender: A Review of the Empirical Evidence, Paper prepared on behalf of Wiego (Women in Informal Employment: Globalizing and Organizing), OECD and World Bank, Washington and Paris, 2002.

Charmes, J. (2007), Informal Sector Poverty and Gender, A Review of Empirical Evidence, Paper prepared on behalf of Wiego (Women in Formal Employment Globalizing and Organizing), OECD and World Bank, Washington and Paris, 2007. 
Charmes, J. (2008), Informal Sector Poverty and Gender, A Review of Empirical Evidence, Paper prepared on behalf of Wiego (Women in Formal Employment Globalizing and Organizing), OECD and World Bank, Washington and Paris 2008.

Chen, M. (2004), Rethinking the Informal Economy: Linkages with the Formal Economy and the Formal Regulatory Environment, Paper presented a the EGDI-WIDR Conference Unleashing Human Potential: Linking the Informal and Formal Sectors, Helsinki, Finland, 2004.

Chickering, L.A. and M. Salahdine (eds.) (1991), The Silent Revolution - The Informal Sector in Five Asian and near Eastern Countries, An International Center for Economic Growth Publication (ICS Press), San Francisco.

De la Roca, J., M. Hernandez, M. Robles, M. Torero and M. Webber (2002), Informal Sector Study for Jamaica, Group of Analysis for Development, Inter-American Development Bank, Washington D.C.

Dell'Anno R., (2003), Estimating the Shadow Economy in Italy: a Structural Equation Approach, Working Paper 2003-7, Department of Economics, University of Aarhus.

Dell'Anno R. (2007), The Shadow Economy in Portugal: An Analysis with the MIMIC Approach, Journal of Applied Economics 10, 253-277.

Dell'Anno, R. and F. Schneider (2004), The Shadow Economy of Italy and other OECD Countries: What Do We Know?, Journal of Public Finance and Public Choice 21, 223245.

Dell'Anno, R. and F. Schneider (2009), A Complex Approach to Estimate Shadow Economy: The Structural Equation Modelling, in: M. Faggnini and T. Looks (eds.), Coping with the Complexity of Economics, Berlin: Springer, pp. 110-130.

Dell'Anno R., M. Gomez-Antonio and A. Alanon Pardo (2007), Shadow Economy in three different Mediterranean Countries: France, Spain and Greece. A MIMIC Approach, Empirical Economics 33, 51-84.

Dixon, H. (1999), Controversy, On the Hidden Economy, Editorial introduction, Economic Journal 456/3, pp.335-337.

Dreher, A. and F. Schneider (2009) Corruption and the Shadow Economy: An Empirical Analysis, Public Choice, 144/2, pp.215-277.

Dreher, A., C. Kotsogiannis and S. McCorriston (2009), How Do Institutions Affect Corruption and the Shadow Economy?, International Tax and Public Finance, 16/4, pp.773796. 
Eck, R. van and B. Kazemier (1988), Features of the Hidden Economy in the Netherlands, Review of Income and Wealth 34/3, pp. 251-273.

Enste, D. and F. Schneider (2006), Umfang und Entwicklung der Schattenwirtschaft in 145 Ländern, in: F. Schneider and D. Enste (eds.), Jahrbuch Schattenwirtschaft 2006/07. Zum Spannungsfeld von Poltik und Ökonomie, LIT Verlag, Berlin, 55-80.

European Commission (2007), Stepping up the fight against undeclared work, COM (2007) 628 final, Brussels: European Commission.

Feige, E.L. (ed.) (1989), The Underground Economies. Tax Evasion and Information Distortion, Cambridge University Press, Cambridge.

Feige, E.L. (1994), The Underground Economy and the Currency Enigma, Supplement to Public Financel Finances Publiques 49, 119-136.

Feld, L.P. and B.S. Frey (2007), Tax Compliance as the Result of a Psychological Tax Contract: The Role of Incentives and Responsive Regulation, Law and Policy 29/1, pp. 102120.

Feld, L.P. and C. Larsen (2005), Black Activities in Germany in 2001 and 2004: A Comparison Based on Survey Data, Study No. 12, The Rockwool Foundation Research Unit, Copenhagen.

Feld, L.P. and C. Larsen (2008), "Black" Activities Low in Germany in 2006, News from the Rockwool Foundation Research Unit, March 2008, 1-12.

Feld, L.P. and C. Larsen (2009), Undeclared Work in Germany 2001-2007 - Impact of Deterrence, Tax Policy, and Social Norms: An Analysis Based on Survey Data, Springer, Berlin et al.

Feld, L.P. and F. Schneider (2010), Survey on the Shadow Economy and Undeclared Earnings in OECD Countries, German Economic Review 11/2, pp. 109-149.

Flaming, D., B. Hayolamak and P. Jossart (2005), Hopeful Workers, Marginal Jobs: LA's Off-The-Books Labor Force, Economic Roundtable, Los Angeles, CA, 2005.

Fleming, M.H., Roman, J. and G. Farrel (2000), The Shadow Economy, Journal of International Affairs, Spring 2000, No. 53/2, 64-89.

Frey, B.S. and W. Pommerehne (1984), The Hidden Economy: State and Prospect for Measurement, Review of Income and Wealth 30/1, pp. 1-23.

Friedman, E., S. Johnson, D. Kaufmann and P. Zoido-Lobatón (2000), Dodging the Grabbing Hand: The Determinants of Unofficial Activity in 69 Countries, Journal of Public Economics 76/4, pp. 459-493. 
Giles, D.E.A. (1999a), Measuring the Hidden Economy: Implications for Econometric Modelling, Economic Journal 109/3, 370-380.

Giles, D.E.A. (1999b), Modelling the Hidden Economy in the Tax-Gap in New Zealand, Empirical Economics 24/ 4, 621-640.

Giles, D.E.A. (1999c), The Rise and Fall of the New Zealand Underground Economy: Are the Reasons Symmetric?, Applied Economic Letters 6, 185-189.

Greenidge, K., C. Holder and S. Mayers (2005), Estimating the Size of the Underground Economy in Barbados, paper presented at the $26^{\text {th }}$ Annual Review Seminar, Research Department, Central Bank of Barbados, July 26-29, 2005.

Haigner, Stefan, Stefan Jenewein, Friedrich Schneider and Florian Wakolbinger (2011), Dissatisfaction, Fear and Annoyance: Driving Forces of Informal Labor Supply and Demand, Discussion Paper, Department of Economics, University of Linz, Linz, Austria. Paper presented at the European Public Choice Meeting, Rennes, April 28 to May 1, 2011.

Heintz, E. and Chang G.B. (2007), Report of Informal Employment for the ILO, ILO Geneva. Herwartz, H., F. Schneider and E. Tafenau (2009), One Share Fits It All? Regional Variation in the Shadow Economy in the EU Regions, Discussion paper, Universities of Linz and Kiel.

Isachsen, A.J. and S. Strøm (1985), The Size and Growth of the Hidden Economy in Norway, Review of Income and Wealth 31/1, 21-38.

Johnson, S., D. Kaufmann and A. Shleifer (1997), The Unofficial Economy in Transition, Brookings Papers on Economic Activity No. 2, pp. 159-221.

Johnson, S., D. Kaufmann and P. Zoido-Lobatón (1998a), Regulatory Discretion and the Unofficial Economy, American Economic Review, Papers and Proceedings 88 (2), 387392.

Johnson, S., D. Kaufmann and P. Zoido-Lobatón (1998b), Corruption, Public Finances and the Unofficial Economy, World Bank Policy Research Working Paper Series No. 2169, The World Bank, Washington, D.C.

Karmann, A. (1986), Monetäre Ansätze zur Erfassung der Schattenwirtschaft: Ein Vergleich verschiedener Messansätze, Kredit und Kapitel 19, 233-247.

Karmann, A. (1990), Schattenwirtschaft und ihre Ursachen: Eine empirische Analyse zur Schwarzwirtschaft und Selbstversorgung in der Bundesrepublik Deutschland, Zeitschrift für Wirtschafts- und Sozialwissenschaften (ZWS) 110, 185-206. 
Kastlunger, B., E. Kirchler, L. Mittore and J. Pitters (2009), Sequences of Audits, Tax Compliance, and Taxpaying Strategies, Journal of Economic Psychology 30/4, pp. 405-418.

Kazemier, B. (2005a), The Undergroud Economy: A Survey of Methods and Estimates, Discussion Paper, Statistics Netherlands, Voorburg, Netherlands.

Kazemier, B. (2005b), Monitoring the Underground Labor Market: What Surveys Can Do, Discussion Paper, Statistics Netherlands, Voorburg, Netherlands.

Kazemir, B. (2006) Monitoring the Underground Economy: A Survey of Methods and Estimates, in: F. Schneider and D. Enste (eds.), Jahrbuch Schattenwirtschaft 2006/07. Zum Spannungsfeld von Politik und Ökonomie, LIT Verlag, Berlin, pp. 11-53.

Kirchler, E. (2007), The Economic Psychology of Tax Behaviour, Cambridge (UK) University Press, Cambridge.

Kirchler, E., E. Hoelzl and I. Wahl (2007), Enforces versus Voluntary Tax Compliance: The „Slippery Slope“ Framework, Journal of Economic Psychology 29/2, pp. 210.225.

Kirchler, E., B. Maciejovsky and F. Schneider (2003) Everyday Representations of Tax Avoidance, Tax Evasion and Tax Flight: Do Legal Differences Matter?, Journal of Economic Psychology 24/4, pp. 535-553.

Kopp, R.J., W.W. Pommerehne and N. Schwarz (1997), Determining the Value of NonMarketed Goods: Economic, Psychological, and Policy Relevant Aspects of Contingent Valuation Methods, Boston, (USA), Kluwer Academic Publishing Company.

Kucera, D. and L. Roncolato (2008), Informal Employment: Two Contested Policy Issues, International Labor Review 147/3, 321-348.

Losby, J.L., J.F. Else, M.E. Kingslow, E.L. Edgcomb, E.T. Malm and V. Kao (2002), Informal Economy Literature Review, The Aspen Institute, Microenterprise Fund for Innovation, Effectiveness, Learning and Dissemination, Washingtion D.C., and ISED Consulting and Research, Newark DE.

Lubell, H. (1991), The Informal Sector in the 1980's and 1990's, OECD, Paris.

Marcelli, E.A. (2004), Unauthorized Mexican Immigration, the Labour and other LowerWage Informal Employment in California, Regional Studies 38/1, pp. 1-13.

Marcelli, E.A., M. Pastor jr. and P.M. Joassart (1999), Estimating the Effects of Informal Economic Activity: Evidence from Los Angeles County, Journal of Economic Issues $33,579-607$.

Merz, J. and K.G. Wolff (1993), The Shadow Economy: Illicit Work and Household Production - A Microanalysis of West Germany, Review of Income and Wealth 39/2, 177-194. 
Mootoo, L., S. Sookram and P.K. Watson (2002), Size and Structure of the Hidden Economy in the Caribbean, Economic Measurement Unit, Department of Economics, University of the West Indies, St. Augustine, Trinidad \& Tobago.

OECD (2009a), Is Informal Normal? Towards More and Better Jobs, OECD, Paris.

OECD (2009b), Policy Round Tables, Competition Policy and the Informal Economy, OECD, Paris.

Pedersen, S. (2003), The Shadow Economy in Germany, Great Britain and Scandinavia: A Measurement Based on Questionnaire Service, Study No. 10, The Rockwool Foundation Research Unit, Copenhagen.

Pozo, S. (ed.) (1996), Exploring the Underground Economy: Studies of Illegal and Unreported Activity, W.E. Upjohn, Institute for Employment Research, Michigan.

Renooy, P., S. Ivarsson, O. van der Wusten-Gritsai and E. Meijer (2004), Undeclared Work in an Enlarged Union - An Analysis of Undeclared Work: An In-Depth Study of Specific Items, European Commission, Brussels.

Schneider, F. (1986), Estimating the Size of the Danish Shadow Economy Using the Currency Demand Approach: An Attempt, Scandinavian Journal of Economics 88/4, 643-668.

Schneider, F. (1994a), Measuring the Size and Development of the Shadow Economy. Can the Causes be Found and the Obstacles be Overcome?, in: H. Brandstaetter and W. Güth (eds.), Essays on Economic Psychology, Springer, Berlin et al., 193-212.

Schneider, F. (1994b), Determinanten der Steuerhinterziehung der Schwarzarbeit im internationalen Vergleich, in: C. Smekal and E. Theurl (eds.), Stand und Entwicklung der Finanzpsychologie, Nomos, Baden-Baden, 247-288.

Schneider, F. (1994c), Can the Shadow Economy be Reduced Through Major Tax Reforms? An Empirical Investigation for Austria, Supplement to Public Financel Finances Publiques 49, 137-152.

Schneider, F. (2001), Die Schattenwirtschaft - Tatbestand, Ursachen, Auswirkungen, in: A. Rauscher (ed.), Die Arbeitswelt im Wandel, J.P. Bachem, Köln, 127-143.

Schneider, F. (2003), Shadow Economy, in: C.K. Rowley and F. Schneider (eds.), Encyclopedia of Public Choice Vol. II, Kluwer Academic Publishers, Dordrecht, 286-296.

Schneider, F. (2005), Shadow Economies around the World: What Do We Really Know? European Journal of Political Economy 21/4, 598-642.

Schneider, F. (2006), Shadow Economies and Corruption All Over the World: What Do We Really Know?, Universität Linz: Institut für Volkswirtschaftslehre, Diskussionspapier, August 2006. 
Schneider, F. (2010), The Influence of Public Institutions on the Shadow Economy: An Empirical Investigation for OECD Countries, European Journal of Law and Economics, 6/3, pp.441-468.

Schneider, F. (eds.), (2011), Handbook on the Shadow Economy, Cheltenham (UK), Edward Elgar Publishing Company.

Schneider, F. and D. Enste (2000a), Schattenwirtschaft und Schwarzarbeit - Umfang, Ursachen, Wirkungen und wirtschaftspolitische Empfehlungen, Oldenbourg, München.

Schneider, F. and D. Enste (2000b), Shadow Economies: Size, Causes and Consequences, Journal of Economic Literature 38/1, 73-110.

Schneider, F. and D. Enste (2002), The Shadow Economy: Theoretical Approaches, Empirical Studies, and Political Implications, Cambridge University Press, Cambridge (UK).

Schneider, F. and D. Enste (eds.) (2006), Jahrbuch Schattenwirtschaft 2006/07. Zum Spannungsfeld von Poltik und Ökonomie, LIT Verlag, Berlin.

Schneider, F. and C.C. Williams (2013), The Shadow Economy, Institute of Economic Affairs, London.

Schneider, F., A. Buehn and C.E. Montenegro (2010), New Estimates for the Shadow Economies all over the World, International Economic Journal 24/4, pp. 443-461.

Schneider, F., J. Volkert and S. Caspar (2002), Schattenwirtschaft und Schwarzarbeit: Beliebt bei vielen - Ein Problem für alle?: Eine Analyse der schattenwirtschaftlichen Aktivitäten in Deutschland (am Beispiel Baden-Württemberg) und mögliche politische Konsequenzen, Nomos, Baden-Baden.

Smith, P. (1994), Assessing the Size of the Underground Economy: The Canadian Statistical Pespectives, Canadian Economic Observer, Catalogue No. 11-010, pp 16-33.

Tafenau, Egle, Helmut Herwartz and Friedrich Schneider (2010), Regional Estimates for the Shadow Economy in Europe, International Economic Journal, 24/4, pp. 629-636.

Tanzi, V. (1999), Uses and Abuses of Estimates of the Underground Economy, Economic Journal 109/3, 338-347.

Teobaldelli, D. (2011), Federalism and the Shadow Economy, Public Choice (2011) 146/3, pp. 269-269.

Teobaldelli, D. and F. Schneider (2012), Beyond the veil of ignorance: The influence of direct democracy on the shadow economy, CESifo Working Paper MO3749, University of Munich, Munich.

Thomas, J.J. (1992), Informal Economic Activity, Harvester/Weatsheaf, New York et al. 
Thomas, J.J. (1999), Quantifying the Black Economy: 'Measurement Without Theory' Yet Again?, Economic Journal 109, 381-389.

Torgler, B. (2002), Speaking to Theorists and Searching for Facts: Tax Morale and Tax Compliance in Experiments, Journal of Economic Survey 16/4, pp. 657-683.

Torgler, B. (2007), Tax Compliance and Tax Morale: A Theoretical and Empirical Analysis, Edward Elgar, Cheltenham (UK).

Torgler, B. and F. Schneider (2009), The Impact of Tax Morale and Institutional Quality on the Shadow Economy, Journal of Economic Psychology 30/3, 228-245.

Vuletin, G. (2008), Measuring the Informal Economy in Latin America and the Caribbean, International Monetary Fund, IMW Working Paper WP/08/102, Washington D.C.

Williams, C.C. and J. Windebank (1998), Informal Employment in the Advanced Economies: Implication for Work and Welfare, Routledge, London.

Williams, C.C. and J. Windebank (2001a), Beyond Profit Motivated Exchange: Some Lessons from the Study of Paid Informal Work, European Urban and Regional Studies 8, 49-61.

Williams, C.C. and J. Windebank (2001b), Reconceptualizing Paid Informal Exchange: Some Lessons from English Cities, Environment and Planning A 33, 121-140. 